\title{
Stres Kerja dengan Produktivitas Kerja Karyawan di PT Politama Pakindo Ungaran
}

\author{
Eka Gerhana Wulansari ${ }^{1}$ \\ Fakultas Psikologi, Program Studi Psikologi, Universitas Kristen Satya Wacana \\ ekagerhanawulansari@gmail.com \\ Sutarto Wijono ${ }^{2}$ \\ Fakultas Psikologi, Program Studi Psikologi, Universitas Kristen Satya Wacana \\ sutarto.wijono@uksw.edu
}

\begin{abstract}
This study aims to determine whether or not there is a relationship between work stress and Work productivity in the production department in PT Politama Pakindo Ungaran. This research was conducted at PT Politama Pakindo Ungaran on Finishing employees with a total population of 148 employees. The sample in this study amounted to 54 the employee in the finishing section with a purposive sampling technique in taking the sample, namely by determining its characteristics in advance to determine the subject in accordance with the phenomenon found in the field. The stress of alone work is measured using psychological measurement tools, the "Work Stress Scale" owned by Robbins (1996) "Job Stress Scale" measurement tool which was developed by the author with a total of 54 items and for work productivity itself uses company data. From the results of data analysis using analytical techniques Pearson who obtained results $r=0.375 ; p<0.05$. The results showed that there was a positive and significant relationship between work stress and employee work productivity at PT Politama Pakindo Ungaran, which indicates that work stress plays a major role in employee productivity.
\end{abstract}

Keywords: job stress, work productivity, correlation.

\begin{abstract}
Abstrak
Penelitian ini bertujuan untuk mengetahui ada atau tidaknya hubungan antara stres kerja dengan produktivitas kerja karyawan pada bagian produksi di PT Politama Pakindo Ungaran. Penelitian ini dilakukan di PT Politama Pakindo Ungaran pada karyawan bagian Finishing dengan jumlah populasinya adalah 148 karyawan. Sampel dalam penelitian ini sebesar 54 karyawan pada bagian finishing dengan teknik purposive sampling dalam pengambilan sampelnya, yaitu dengan menentukan karakteristiknya terlebih dahulu untuk menentukan subjek yang sesuai dengan fenomena yang ditemukan di lapangan. Stres kerja sendiri diukur dengan menggunakan alat ukur psikologi yaitu “The Job Stress Scale” milik Robbins (1996) yang telah dikembangkan oleh penulis dengan total item sebanyak 54 item dan untuk produktivitas kerja sendiri menggunakan data perusahaan. Dari hasil analisis data menggunakan teknik analisis korelasi Pearson yang memperoleh hasil $r=0,375 ; p<0.05$. Hasil penelitian menunjukkan bahwa terdapat hubungan yang positif dan signifikan antara stres kerja dengan produktivitas kerja karyawan di PT Politama Pakindo Ungaran yang menandakan bahwa stres kerja beperan besar terhadap produktivitas kerja pada diri karyawan..
\end{abstract}

Kata kunci: stres kerja, produktivitas kerja, korelasi. 


\section{PENDAHULUAN}

Dalam era globalisasi masa sekarang, dapat diketahui bahwa persaingan bisnis semakin ketat sehingga dalam membangun perusahaan yang efektif, efisien, dan produktif merupakan sebuah tantangan yang sulit (Zulkarnaen, Suarsa, dan Kusmana, 2018). Terutama dalam era revolusi industri 4.0, perusahaan harus mampu menciptakan sebuah produk atau menjadikan jasa yang lebih unggul dari para pesaing. Pernyataan tersebut didukung oleh Asbari, Santoso, dan Purwanto (2019) dalam penelitiannya yang menyatakan bahwa, pada era digital seperti saat ini perusahaan sangat membutuhkan SDM yang memiliki derajat inovasi dan kreativitas yang tinggi sehingga perusahaan harus memiliki SDM yang berkualitas. Perusahaan sebagai distributor barang maupun jasa bagi masyarakat luas, patut untuk menyediakan kebutuhan masyarakat terkhusus pada era revolusi industri 4.0. Masih banyak SDM dalam perusahaan yang memiliki keterampilan terbatas ketika harus bekerja dengan mengikuti perkembangan zaman, hal tersebut dapat menjadi sebuah kendala untuk kemajuan perusahaan (Spector, 2006). Semakin berkembangnya zaman maka dapat mempengaruhi perilaku SDM, sehingga dapat menimbulkan sebuah permasalahan dalam perusahaan. Oleh karena, setiap organisasi sendiri akan di tentukan dari perilaku SDM di dalamnya. Hal tersebut selaras dengan pernyataan dari Tahir (2014) yang mengatakan bahwa sebuah perbedaan karakteristik dan perilaku setiap SDM dapat menjadi permasalahan utama dalam organisasi itu sendiri. Tingkatan hasil produktivitas yang dirasakan setiap SDM dalam bekerja dapat mempengaruhi timbulnya sebuah permasalahan dalam organisasi (Damri, 2017).

Produktivitas kerja menjadi aktiva yang paling berpengaruh, dengan meningkatnya produktivitas kerja maka juga akan mempengaruhi perkembangan perusahaan itu sendiri (Harrisma \& Witjaksono, 2013). Hal tersebut yang sedang terjadi pada perusahaan yang telah menjadi tempat penelitian penulis yaitu PT Politama Pakindo Ungaran yang bergerak dibidang manufaktur plastik. Saat ini perusahaan tersebut sedang mengalami beberapa kendala yang berkaitan dengan produktivitas kerja, terutama pada karyawan produksi di bagian finishing yang dilihat memiliki produktivitas kerja yang kurang stabil. Penulis mencermati hal tersebut sehingga sangat perlu untuk melakukan observasi dan wawancara berkaitan dengan produktivitas kerja. Penulis melakukan observasi dan wawancara pada tanggal 24 Juni 2019, terhadap sepuluh orang karyawan secara bertatap muka. Berdasarkan hasil dari observasi yang telah dilakukan oleh penulis pada bagian finishing masih ditemukan kesalahan dalam proses pencetakan plastik dalam kurun waktu tertentu. Hasil dari produktivitas kerja karyawan bagian 
finishing dalam memproduksi plastik sendiri masih belum stabil perbulannya. Berdasarkan dari hasil wawancara ditemukan bahwa terdapat enam karyawan yang mengaku bahwa, mereka mampu bekerja secara optimal sehingga target produksi dapat terpenuhi, hanya saja apabila terjadi kesalahan dalam pencetakkan barang maka hasil yang diperoleh menjadi tidak sesuai dengan target yang diberikan perusahaan. Terdapat empat karyawan yang mengaku bahwa mutu barang yang diproduksi terkadang tidak sesuai dengan ketentuan, dan produksi barang seringkali memiliki kualitas yang buruk diakibatkan karena bahan yang tersedia memiliki kualitas yang kurang bagus, sehingga mereka diharuskan untuk memperbaiki produk tersebut. Atas dasar fenomena tersebut bisa dikatakan bahwa terdapat permasalahan yang terkait dengan produktivitas kerja pada karyawan bagian finishing di PT Politama Pakindo Ungaran.

Oleh karena itu, penelitian tentang produktivitas penting dilakukan di PT Politama Pakindo Ungaran. Dengan kata lain, produktivitas merupakan sebuah keunggulan yang kompetitif untuk mencapai keberhasilan suatu organisasi (Rawal \& Mhatre, 2018). Adapula hasil penelitian dari Cherny dan Kartikasari (2017) yang menegaskan bahwa setiap perusahaan berharap seluruh karyawan dapat bekerja secara benar dan teliti, sehingga dapat meningkatkan produktivitas kerjanya. Pada akhirnya, karyawan akan mampu mewujudkan visi maupun misi yang telah disepakati untuk mencapai tujuan utama dalam perusahaan.

Dalam kesempatan lain, Golden (2012) mengatakan ada dampak positif yang terkait dengan produktivitas berkaitan dengan pengaturan waktu kerja yang lebih flaksibel atau inovatif. Hal tersebut berati bahwa waktu kerja akan terkompresi, dengan rata-rata jam kerja pada karyawan perminggunya. Adapun dampak negatif dari produktivitas kerja yang tidak terpenuhi adalah peningkatan sebuah perekrutan karyawan, sehingga akan menghambat biaya dalam perusahaan. Selain itu, McTague (dalam Timpe, 2002) yang menyatakan bahwa terdapat dampak positif pada produktivitas, yaitu dengan meningkatnya output maka meningkatkan nilai tambah terhadap hasil produksi, dan apabila produktivitas rendah maka dapat menghambat jalannya bisnis tersebut. Dengan demikian, maka seluruh sistem akan terhambat diantaranya pengiriman barang menjadi tertunda.

Saefullah, Listiawati, dan Amalia (2017) menjelaskan bahwa menurunnya produktivitas kerja dipengaruhi oleh adanya kelelahan bekerja; target yang terlalu tinggi, tuntutan terhadap peran yang kurang jelas, tekanan (stres), minimnya waktu, beban kerja yang berlebihan, dan pesanan yang meningkat dengan tenaga kerja yang sedikit sehingga memaksa karyawan untuk bekerja lembur. Hal tersebut yang mengakibatkan kelelahan sehingga berakibat pada penurunan produktivitas kerja. Pernyataan tersebut didukung oleh pernyataan 
dari Tarwaka, Bakri, dan Sudiajeng (2004) dalam penelitiannya yang mengungkapkan bahwa, faktor yang mempengaruhi produktivitas kerja antara lain yaitu pendidikan, kedisiplinan kerja, keterampilan dalam bekerja, motivasi kerja, etos kerja, dan stres kerja. Stres kerja merupakan salah satu faktor yang mempengaruhi produktivitas kerja di dalam organisasi. Apabila stres kerja meningkat, maka dapat mengakibatkan produktivitas kerja menjadi rendah. Oleh sebab itu, stres kerja menjadi penting untuk diteliti karena stres kerja sendiri dapat menjadi faktor utama menurunnya produktivitas kerja, peningkatan absensi dan pengumpulan masalah karyawan lainnya seperti alkoholisme, penyalahgunaan narkoba, hipertensi, dan sejumlah masalah kardiovaskular Meneze (dalam Dar, Akmal, Naseem, dan Khan, 2011).

Adapun hasil-hasil penelitian mengenai stres kerja dengan produktivitas kerja karyawan telah dilakukan oleh beberapa peneliti. Penelitian yang dimaksud adalah Bamidele, Adedeji, dan Samuel (2014) yang menemukan bahwa stres secara positif berpengaruh signifikan terhadap kinerja karyawan, sehingga berdampak pula terhadap produktivitas kerja karyawan itu sendiri. Selanjutnya, Cherny dan Kartikasari (2017) mengungkapkan bahwa stres kerja berpengaruh positif dan tidak signifikan pada produktivitas kerja, sehingga tidak berdampak pada produktivitas karyawan. Dengan kata lain, produktivitas berjalan lancar walaupun karyawan sedang mengalami stres kerja. Temuan tersebut didukung oleh Lucia, Kawet, dan Trang (2015) yang menyatakan bahwa stres kerja tidak berpengaruh terhadap produktivitas kerja. Kemudian muncul persepsi bahwa terdapat sesuatu perbedaan diantara unsur stres dan unsur produktivitas kerja, karena stres sendiri sering dihubungkan dengan sebuah situasi yang emosional dari individu itu sendiri sedangkan produktivitas kerja lebih dihubungkan dengan sebuah tanggung jawab dari pribadi terhadap organisasi. Unsur emosional dari individual kurang dapat menjadi penghalang tugas dari karyawan untuk mencapai produktivitas kerja, akan tetapi stres kerja memberikan pengaruh positif bagi poduktivitas karyawan. Sebaliknya temuan, Harrisma dan Witjaksono (2013) menyatakan stres kerja berpengaruh negatif dan signifikan pada produktivitas. Hal ini disebabkan oleh tuntutan tugas, tuntutan antar pribadi, tuntutan peran, kepemimpinan organisasi, dan juga struktur organisasi, sehingga dapat menurunkan produktivitas karyawan dalam bekerja.

Penulis menganggap bahwa penelitian yang penulis lakukan ini ada perbedaan dengan hasil penelitian yang dilakukan oleh para peneliti sebelumnya. Pernyataan tersebut ditunjukkan oleh temuan Dwamena (2012) di kota Takoradi Ghana yang membahas mengenai stres dan efeknya terhadap produktivitas. Penelitian dengan variabel stres kerja tersebut menggunakan teori dari Bennett (1994). Sementara itu, produktivitas kerja menggnakan teori dari Chase dan 
Aquilano (1995). Metode yang digunakan adalah metode deskriptif, dengan tehnik purposive dan simple random sampling. Responden dalam penelitian tersebut adalah karyawan pada bagian Pemasaran, Keuangan, Operasi Pelabuhan, Teknik Kelautan, dan departemen Teknik Sipil GPHA, di Takoradi.

Dalam penelitian ini, penulis menggunakan teori stres kerja dari Robbins (1996) dan teori produktivitas kerja dari Mathis dan Jackson (2008). Penulis menggunakan metode penelitian korelasional dengan tehnik purposive sampling. Responden dalam penelitian ini adalah karyawan pada bagian finishing di PT Politama Pakindo Ungaran. Berdasarkan perbedaan-perbedaan tersebut, maka dapat dikatakan bahwa penelitian mengenai stres kerja dengan produktivitas kerja masih penting untuk diteliti kembali terkhususnya di PT Politama Pakindo Ungaran. Jadi, penulis tertarik untuk meneliti mengenai "Stres kerja dengan produktivitas kerja karyawan" di PT Politama Pakindo Ungaran. Tujuan dalam penelitian ini adalah untuk mengetahui ada atau tidaknya hubungan antara stres kerja dengan produktivitas kerja karyawan di PT Politama Pakindo Ungaran.

Dalam kesempatan lain, Robbins (2003) menjelaskan bahwa produktivitas kerja dapat diukur dari bagaimana karyawan menghasilkan sebuah output yang diinginkan oleh perusahaan secara efisien, sehingga dapat dikatakan bahwa produktivitas sebagai ukuran dari kinerja karyawan yang mencakup efektivitas dan efisiensi. Selanjutnya, Wingjosoebroto (1992) dalam penelitiannya mengungkapkan bahwa produktivitas kerja karyawan dapat diukur secara subyektif, yaitu dengan melihat segala upaya yang menjadi pekerjaan dengan memanfaatkan sumber daya manusia yang tersedia dalam menghasilkan sebuah hasil. Adapun penelitian dari Mahoney, Jardee, dan Caroll (1963) yang menjelaskan bahwa produktivitas kerja juga dapat diukur secara obyektif melalui hasil dari produktivitas yang dihasilkan karyawan, seperti output yang diperoleh karyawan per jamnya. Sedangkan menurut Mathis dan Jackson (2008) sebuah produktivitas yang baik tidak selalu berarti akan lebih banyak output, lebih sedikit orang, uang, dan waktu yang digunakan untuk menghasilkan jumlah barang yang sama, melainkan produktivitas sendiri merupakan sebuah ukuran dari kuantitas dan kualitas yang dijalankan oleh karyawan.

Kemudian dalam penelitian ini, penulis menggunakan sebuah pengukuran produktivitas secara obyektif yaitu dengan menggunakan pengukuran dari hasil produktivitas kerja perusahaan secara langsung dan nyata. Alasan penulis menggunakan pengukuran secara obyektif adalah karena dengan pengukuran tersebut dapat melihat perbandingan antara keluaran dan masukan persatuan waktu yang telah diberikan, sehingga mempermudah penulis 
untuk dapat melihat hasil kerja nyata dari karyawan dan mempermudah dalam pengolahan datanya.

Terdapat dua aspek produktivitas menurut Mathis dan Jackson (2008) antara lain: 1) Aspek kualitas, merupakan sebuah tingkatan produktivitas kerja terhadap masing-masing karyawan yang dapat dilihat dari keterampilan khusus (inovatif) atau pemberian kompetensi inti dari karyawan ke perusahaan. 2) Aspek kuantitas, merupakan jumlah produk yang dihasilkan oleh karyawan lebih besar dari tenaga kerja lainnya, sehingga dapat dikatakan bahwa karyawan yang memiliki kuantitas baik mampu memanfaatkan waktu dengan seefisien mungkin.

Adapun faktor yang mempengaruhi produktivitas kerja menurut Michac (1997) yaitu buruknya pelatihan dalam organisasi, kerusakan mesin, tidak adanya penetapan mengenai standar kinerja, kurangnya perencanaan dan juga motivasi, perubahan, buruknya tata letak, tempat kerja dan lingkungan kerja yang buruk, kurangnya pengorganisasian kerja, rendahnya pengawasan, stres kerja tinggi, banyaknya jam lembur, gagalnya pengontrolan, kurangnya komunikasi yang baik, tidak mengidentifikasi tujuan organisasi, kurangnya kreatifitasan, dan konflik kerja.

Menurut Stranks (2005) stres kerja merupakan sebuah keadaan psikologis yang dapat mengakibatkan seseorang memiliki perilaku yang salah ditempat kerja dan stres kerja sendiri merupakan hasil dari respons orang terhadap ketidakseimbangan antara tuntutan dengan kemampuan karyawan. Definisi lebih lanjut mengenai stres kerja dikemukakan oleh The Health and Safety Executive (HSE) (dalam Stranks, 2005) bahwa stres kerja sebagai tekanan dan tuntutan yang ekstrem yang ditempatkan pada seseorang di luar kemampuannya. Adapula pernyataan Robbins (1996) mengenai stres kerja yaitu merupakan suatu keadaan yang dinamik yang dialami oleh seorang karyawan ditempat kerja yang dipertentangkan dengan adanya sebuah kendala, peluang, maupun tuntutan yang berkaitan dengan adanya suatu keinginan dan juga hasil sebagai sesuatu yang tidak pasti atau tidak penting.

Adapun aspek-aspek stres kerja menurut Robbins (1996) antara lain: 1) Aspek fisiologis, seseorang yang mengalami stres dapat menyebabkan metabolisme tubuh menjadi berubah, yang meliputi keluhan/ sakit pada fisik seperti; sakit kepala, sakit punggung, merasa lelah, sakit perut, detak jantung meningkat dan naiknya tekanan darah. 2) Aspek psikologis, seseorang cenderung akan merasa depresi dan sering tidak puas dengan sesuatu, yang meliputi yaitu; sering merasa gelisah (cemas), mudah bosan, mudah marah, sering menunda-nunda pekerjaan, sering merasa tegang, dan merasa tertekan. 3) Aspek perilaku, individu akan 
cenderung mengalami perubahan dalam tingkah lakunya seperti; meningkatkan ketergantungan terhadap alkohol atau rokok, sering adu argumentasi dengan orang lain, sering membatalkan janji, tidak konsisten, kurang nafsu makan atau nafsu makan berlebihan, tingkat absensi meningkat, mudah gelisah, dan bicara cepat.

Pada kesempatan lain, Harrisma dan Witjaksono (2013) mengatakan bahwa organisasi memiliki salah satu faktor utama yaitu manusia yang menjadi bagian penting dalam mencapai keberhasilan sebuah organisasi. Oleh sebab itu, pimpinan organisasi berusaha mencapai berbagai usaha dan aktivitas dalam mendukung para karyawannya untuk memperoleh hasil yang maksimal sehingga dapat mencapai produktivitas yang tinggi. Dalam mencapai sebuah produktivitas yang tinggi diharapkan karyawan mampu beradaptasi dengan perubahan perkembangan teknologi dalam perusahaan. Ketika karyawan tidak memiliki kemampuan beradaptasi maka ia akan mengalami perasan tertekan atau yang bisa mengakibatkan stres, karena adanya stres tersebut akan menghambat tercapainya produktivitas yang tinggi. Pernyataan tersebut didukung oleh hasil temuan dari Lucia, Kawet, dan Trang (2015) yang mengatakan bahwa ketika karyawan kurang dapat menyesuaikan teknologi maka mereka mengalami stres, dan hal tersebut akan mempengaruhi poduktivitas kerja.

Atas dasar penjelasan di atas, maka Stranks (2005) memberikan penekanan kembali bahwa sebuah perilaku karyawan yang kurang mampu dalam menanggapi tuntutan kerja akan menyebabkan karyawan mengalami tekanan kerja, sehingga mengakibatkan munculnya stres kerja. Stres kerja dapat timbul secara alami dan tidak dapat dikendalikan dalam kehidupan seseorang, sehingga kemampuan untuk berfikir secara logis akan menjadi terganggu, hal ini secara langsung akan mempengaruhi tingkat produktivitas yang dihasilkan. Keterkaitan antara stres kerja dan produktivitas kerja pada karyawan dapat ditegaskan bahwa apabila stres kerja tinggi maka produktivitas kerja rendah, begitu pula sebaliknya apabila stres kerja rendah maka tingkat produktivitas kerja akan semakin tinggi dan apabila stres kerja tinggi, maka tingkat produktivitas kerja juga akan tinggi, sehingga ketika stres kerja turun maka tingkat produktivitas kerja juga akan rendah. Hal tersebut selaras dengan pernyataan dari Andriani (2017) berdasarkan hasil dari analisis memperoleh hasil bahwa stres kerja memiliki hubungan terhadap produktivitas kerja pada pegawai, yang artinya bahwa jika stres kerja pada pegawai maningkat maka produktivitas akan mengalami penurunan dapat juga sebaliknya. Terdapat juga penelitian dari Putri (2015) bahwa stres memiliki pengaruh yang positif terhadap produktivitas kerja karyawan, dengan berpengaruhnya stres bagi produktivitas kerja terhadap 
karyawan maka secara umum dapat dilihat bahwa apabila tingkat stres rendah maka dapat meningkatkan kinerja dan perubahan yang baik.

Ada beberapa hasil penelitian yang mengungkapkan adanya hubungan stres kerja dengan produktivitas kerja. Penelitian dari Sorongan, Suoth, dan Boky (2018) mengungkapkan bahwa terdapat hubungan antara produktivitas kerja dengan stres kerja pada pegawai. Kemudian Harrisma dan Witjaksono (2013) bahwa stres kerja memiliki pengaruh yang negatif dan signifikan terhadap produktivitas kerja. Akan tetapi pernyataan tersebut berbanding terbalik dengan pernyataan dari Lucia, Kawet, dan Trang (2015) dalam penelitiannya mengungkapkan bahwa stres kerja secara persial tidak memiliki pengaruh terhadap produktivitas kerja, yang berarti bahwa semakin tinggi tingkat stres kerja maka tidak akan mempengaruhi sebuah produktivitas kerja pada karyawan. Dari hasil penelitian sebelumnya terdapat dinamika psikologis hubungan diantara stres kerja dengan produktivitas kerja maka penulis menganggap bahwa penelitian mengenai dua variabel tersebut masih dapat dilakukan di PT Politama Pakindo Ungaran.

Berdasarkan dinamika psikologis hubungan antara dua variabel yang telah dikemukakan, maka hipotesis dalam penelitian ini adalah terdapat hubungan antara stres kerja dengan produktivitas kerja karyawan di PT Politama Pakindo Ungaran.

\section{METODE PENELITIAN}

Pada penelitian yang dilakukan penulis menggunakan pendekatan kuantitatif, yang menggunakan data-data berupa angka yang dikumpulkan melalui prosedur angka kemudian diolah menggunakan metode analisis statistika (Azwar, 2018). Sedangkan tujuan pada penelitian ini adalah sebuah penelitian korelasional. Pada penelitian korelasional, penulis akan mendapatkan sebuah informasi mengenai hubungan timbal-balik yang terjadi antar variabel.

Pada penelitian ini, penulis mengambil data di PT Politama Pakindo Ungaran, dengan populasinya adalah seluruh karyawan produksi pada bagian Finishing dengan jumlah 148 karyawan. Penulis menggunakan teknik purposive sampling dalam pemilihan sampelnya yaitu teknik sampel yang didasarkan atas pertimbangan penulis dengan ciri-ciri tertentu (Sugiyono, 2011), antara lain sebagai berikut;

1. Karyawan yang memiliki masa kerja minimal 1 tahun

2. Merupakan karyawan tetap PT Politama Pakindo Ungaran

3. Karyawan yang memiliki produktivitas yang kurang stabil dalam periode bulan Maret Juni tahun 2019 
Dari berbagai ciri-ciri diatas penulis memperoleh 55 subjek yang sesuai dengan ketentuan, sehingga dapat dijadikan sampel dalam penelitian maka dari itu 55 subjek tersebut diharuskan untuk mengisi angket yang telah dibagikan. Akan tetapi dari sampel penelitian tersebut terdapat satu angket yang tidak dikembalikan, sehingga penulis hanya dapat mengolah data dari 54 subjek.

Pada proses pengambilan data penulis menggunakan satu skala psikologi yang telah penulis kembangkan yaitu "The Job Stress Scale" milik Robbins (1996). Hal pertama yang dilakukan oleh penulis adalah memperoleh izin terlebih dahulu untuk melakukan observasi di lapangan, wawancara, dan juga memperoleh izin untuk melakukan penelitian lanjut di perusahaan. Pada proses awal penulis melakukan identifikasi terlebih dahulu mengenai fenomena-fenomena yang berkaitan dengan aspek-aspek dari produktivitas dan juga stres kerja. Penulis memperoleh fenomena tersebut melalui observasi di lapangan dan juga wawancara terhadap 10 karyawan pada 24 Juni 2019 di area perusahaan secara tatap muka.

Setelah fenomena diperoleh, penulis meminta jumlah keseluruhan karyawan pada bagian Finishing sebagai acuan dari populasi dan pengambilan sampel. Pengambilan sampel sendiri penulis menggunakan teknik purposive sampling dengan ciri-ciri tertentu. Ciri-ciri tersebut antara lain; Karyawan yang memiliki masa kerja minimal 1 tahun, Merupakan karyawan tetap PT Politama Pakindo Ungaran, Karyawan yang memiliki produktivitas yang kurang stabil dalam periode bulan Maret - Juni tahun 2019. Dari jumlah keseluruhan karyawan bagian finishing yaitu 148 karyawan terdapat 55 karyawan yang memiliki ciri-ciri yang sesuai dengan apa yang telah ditentukan penulis, sehingga 55 karyawan tersebut dijadikan sampel dalam penelitian.

Sebelum melakukan penyebaran angket penulis mencari 5 orang karyawan untuk mengoreksi aitem-aitem dari skala. Ketika penulis telah memperoleh hasil koreksi, kemudian mengkonsultasikannya kepada dosen pembimbing. Sehingga setelah mendapatkan persetujuan dari dosen pembimbing, skala diperbanyak sesuai dengan jumlah sampel yang ada yaitu 55 angket. Langkah selanjutnya adalah menyebarkan angket kepada 55 subjek terpilih, akan tetapi setelah angket dikembalikan kepada penulis terdapat satu angket yang tidak dikembalikan oleh subjek.

Penulis menggunakan satu skala psikologi yaitu "The Job Stress Scale" milik Robbins (1996) yang digunakan untuk mengukur stres kerja. Pada skala tersebut terdapat 20 aitem yang kemudian penulis kembangkan menjadi 54 aitem dengan tiga aspek yaitu aspek fisiologis, aspek psikologis, dan aspek perilaku. Menurut Azwar (2012) dalam kriteria validitas alat tes 
dikatakan valid apabila memiliki koefisien korelasi aitem total $\geq 0,30$. Pada skala stres kerja sendiri, hasil dari seleksi aitem hanya tersisa 33 aitem yang valid dan bergerak mulai dari 0,305 - 0,748 dengan koefisien Alpha Cronbach sebesar $(\alpha)$ 0,927. Hal tersebut menunjukkan bahwa skala stres kerja mempunyai tingkat reliabilitas yang sangat tinggi Guilford-Fuhcher (dalam Azwar, 2012).

Pada data yang diperoleh dalam penelitian ini diolah dengan uji korelasi Pearson dan dalam pengolahannya penulis menggunakan alat bantu SPSS Statistics 21.0 for windows.

\section{HASIL DAN PEMBAHASAN}

Tabel 1.

Uji Validitas dan Reliabilitas

\begin{tabular}{l}
$\overline{\text { Reliability Statistics }}$ \\
$\begin{array}{l}\text { Cronbach's N of Items } \\
\text { Alpha }\end{array}$ \\
\hline, 927 \\
\hline
\end{tabular}

Berdasarkan pada tabel 1 dapat dilihat bahwa hasil dari uji reliabilitas memperoleh nilai sebesar 0,927 yang artinya bahwa pada skala stres kerja memiliki tingkat reliabilitas yang sangat tinggi Guilford-Fuhcher (dalam Azwar, 2012) dengan 33 aitem yang valid.

Tabel 2.

Analisis Deskriptif

Kategorisasi Produktivitas Kerja

\begin{tabular}{llllll}
\hline & & Frequency & Percent & Valid Percent & Cumulative Percent \\
\hline \multirow{4}{*}{ Valid } & Rendah & 1 & 1,9 & 1,9 & 1,9 \\
\cline { 2 - 6 } & Sedang & 5 & 9,3 & 9,3 & 11,1 \\
\cline { 2 - 6 } & Tinggi & 48 & 88,9 & 88,9 & 100,0 \\
\cline { 2 - 6 } & Total & 54 & 100,0 & \multicolumn{2}{c}{100,0} \\
\cline { 2 - 5 }
\end{tabular}

Berdasarkan pada tabel 2 dapat dilihat bahwa dalam kategorisasi skor variabel produktivitas kerja dari 54 subjek yang menunjukkan bahwa tingkat penyebaran kategori dari Rendah hingga Tinggi. Sehingga bisa dilihat bahwa pada variabel produktivitas kerja yang termasuk ke dalam kategori "Rendah" memperoleh hasil persentase sebesar 1,9\%, kemudian pada kategori "Sedang” hasil persentase sebesar 9,3\%, dan yang terakhir adalah pada kategori “Tinggi" dengan hasil persentase sebesar $88,9 \%$. Berdasarkan data tersebut dapat disimpulkan bahwa karyawan memiliki stres kerja yang tinggi. 
Tabel 3 .

Kategorisasi Stres Kerja

\begin{tabular}{llllll}
\hline & & Frequency & Percent & Valid Percent & Cumulative Percent \\
\hline \multirow{4}{*}{ Valid } & Rendah & 5 & 9,3 & 9,3 & 9,3 \\
\cline { 2 - 6 } & Sedang & 17 & 31,5 & 31,5 & 40,7 \\
\cline { 2 - 6 } & Tinggi & 32 & 59,3 & 59,3 & 100,0 \\
\cline { 2 - 6 } & Total & 54 & 100,0 & 100,0 & \\
\cline { 2 - 6 }
\end{tabular}

Berdasarkan pada tabel 3 dapat dilihat bahwa dalam kategorisasi skor variabel stres kerja dari 54 subjek yang menunjukkan bahwa tingkat penyebaran kategori dari Rendah hingga Tinggi. Sehingga bisa dilihat bahwa pada kategori "Rendah" memperoleh hasil persentase sebesar 9,3\%, kemudian pada kategori "Sedang" memperoleh hasil persentase sebesar 31,5\%, dan yang terakhir adalah pada kategori "Tinggi" dengan hasil persentase sebesar 59,3\%. Berdasarkan data tersebut dapat disimpulkan bahwa karyawan memiliki stres kerja yang tinggi.

Tabel 4.

Uji Normalitas

\begin{tabular}{lll}
\hline \multicolumn{2}{l}{ One-Sample Kolmogorov-Smirnov Test } \\
\hline $\mathrm{N}$ & & Unstandardized Residual \\
\hline Normal Parameters & & 54 \\
\hline \multirow{3}{*}{ Most Extreme Differences } & Mean &, 0000000 \\
\cline { 2 - 3 } & Std. Deviation & 1,57941777 \\
\cline { 2 - 3 } & Absolute &, 160 \\
\cline { 2 - 3 } & Positive &, 066 \\
\hline Kolmogative &,- 160 \\
\hline Asymp. Sig. (2-tailed) & & 1,174 \\
\hline $\begin{array}{l}\text { a. Test distribution is Normal. } \\
\text { b. Calculated from data. }\end{array}$ &
\end{tabular}

Berdasarkan pada tabel 4 dapat dilihat bahwa hasil dari uji normalitas yang telah penulis lakukan menggunakan uji Kolmogrov-Smirnov Z memperoleh nilai signifikansi Asymp. Sig (2-tailed) sebesar 0,127. Sehingga dapat disimpulkan bahwa data berdistribusi normal. 
Tabel 5 .

Uji Linieritas

\begin{tabular}{|c|c|c|c|c|c|c|c|}
\hline \multicolumn{8}{|c|}{ ANOVA Table } \\
\hline & & & $\begin{array}{l}\text { Sum of } \\
\text { Squares }\end{array}$ & & $\begin{array}{l}\text { Mean } \\
\text { Square }\end{array}$ & $\mathrm{F}$ & Sig. \\
\hline \multirow{7}{*}{$\begin{array}{l}\text { Produktivitas } \\
\text { Kerja * Stres } \\
\text { Kerja }\end{array}$} & \multirow{5}{*}{$\begin{array}{l}\text { Between } \\
\text { Groups }\end{array}$} & (Combined) & 126,840 & 27 & 4,698 & 4,533 &, 000 \\
\hline & & Linearity & 21,571 & 1 & 21,571 & 20,816 &, 000 \\
\hline & & Deviation & 105,268 & 26 & 4,049 & 3,907 &, 000 \\
\hline & & from & & & & & \\
\hline & & Linearity & & & & & \\
\hline & Within Groups & & 26,943 & 26 & 1,036 & & \\
\hline & Total & & 153,783 & 53 & & & \\
\hline
\end{tabular}

Berdasarkan pada tabel 5 dapat dilihat bahwa hasil dari uji linearitas, memperoleh hasil bahwa ada hubungan yang linier antara variabel stres kerja dengan variabel produktivitas kerja, dengan Deviation from Linearity sebesar 3,907 dan nilai signifikansi sebesar 0,000.

Berdasarkan dari uji asumsi yang telah dilakukan oleh penulis diketahui bahwa kedua variabel berdistribusi normal dan linier. Sehingga dalam uji korelasi penulis menggunakan uji statistik parametrik, dengan uji korelasi Pearson.

Tabel 6.

Uji Korelasi

\begin{tabular}{llll}
\hline Correlations & & & \\
\hline \multirow{3}{*}{ Stres Kerja } & & Stres Kerja & Produktivitas Kerja \\
\cline { 2 - 4 } & Pearson Correlation & 1 &, $375^{* *}$ \\
\cline { 2 - 4 } Sig. (2-tailed) & &, 005 \\
\hline \multirow{2}{*}{ Produktivitas Kerja } & $\mathrm{N}$ & 54 & 54 \\
\cline { 2 - 4 } & Pearson Correlation &, $375^{* *}$ & 1 \\
\cline { 2 - 4 } & Sig. (2-tailed) &, 005 & \\
\cline { 2 - 4 } & $\mathrm{N}$ & 54 & 54 \\
\hline
\end{tabular}

**. Correlation is significant at the 0.01 level (2-tailed).

Berdasarkan pada tabel 6 dapat dilihat bahwa hasil dari uji korelasi menggunakan analisis korelasi Pearson, memperoleh hasil korelasi sebesar 0,375 dengan signifikansi sebesar 0,005 yang artinya bahwa dari hasil analisis kedua variabel menunjukkan adanya hubungan positif dan signifikan antara stres kerja dengan produktivitas kerja.

Pada penelitian ini, penulis telah merumuskan sebuah hipotesis dalam penelitian yaitu terdapat hubungan antara stres kerja dengan produktivitas kerja karyawan di PT Politama Pakindo Ungaran. Berdasarkan hasil dari uji korelasi Pearson yang telah dilakukan oleh penulis memperoleh nilai koefisien korelasi sebesar 0,$375 ; \mathrm{p}<0,05$. Jadi, terdapat hubungan yang positif dan signifikan antara stres kerja dengan produktivitas kerja. Dengan kata lain, 
semakin tinggi stres kerja, maka semakin tinggi pula produktivitas kerja karyawan. Hal ini dapat disebabkan oleh beberapa kemungkinan, pertama, sebagian besar karyawan menganggap bahwa stres kerja adalah bagian yang harus dilihat sebagai tantangan yang dapat membuat mereka lebih bersemangat dalam bekerja sehingga dapat membuat karyawan bekerja lebih produktif. Pernyataan tersebut didukung oleh hasil penelitian dari Cherny dan Kartika (2017), Bamidele, Adedeji, dan Samuel (2014), serta Charity (2016) yang menyatakan bahwa ada hubungan positif dan signifikan antara stres kerja dengan produktivitas kerja karyawan.

Kedua, sebagian karyawan menganggap stres menjadi bagian dalam kegiatan keseharian dalam organisasi yang membuat karyawan bekerja lebih fokus untuk meningkatkan produktivitas kerja mereka. Pernyataan tersebut didukung oleh Sunyoto (2007) yang menyatakan bahwa stres kerja yang dialami oleh karyawan mampu berkembang kearah yang positif, artinya bahwa stres sendiri mampu menjadi sebuah kekuatan yang positif bagi karyawan disertai dengan sebuah dorongan yang tinggi untuk meraih prestasi dengan tingkat stres akan semakin tinggi, produktivitas kerja dan efisiensinya juga semakin tinggi. Selanjutnya, menurut Rawal dan Mhatre (2018) mengungkapkan bahwa stres positif dapat dilihat sebagai peluang bagi karyawan dalam organisasi yang percaya akan mendapatkan hasil yang baik.

Ketiga, stres kerja yang dialami oleh karyawan sendiri dipicu oleh faktor organisasi. Dimana organisasi sendiri memberikan sebuah tuntutan tugas, tuntutan peran, dan sebuah tuntutan antar pribadi kepada setiap karyawan yang pada akhirnya dapat menimbulkan stres kerja dalam diri karyawan. Banyaknya tuntutan yang membebani karyawan, tidak sedikit dari mereka merasa banyak perubahan pada fisik, psikologis, maupun perilaku mereka. Hal tersebut tidak menjadi sebuah halangan bagi mereka untuk tetap bekerja dan menyelesaikan tuntutan yang telah diberikan perusahaan, sehingga mereka tetap dapat memenuhi produktivitas kerja. Pernyataan tersebut selaras dengan hasil temuan Safitri dan Gilang (2019) dalam penelitiannya mengungkapkan bahwa faktor yang menimbulkan stres kerja adalah faktor lingkungan, faktor organisasi, dan faktor stres individu. Dalam penelitian tersebut memperoleh hasil bahwa sebuah organisasi harus menekankan dampak dari stres kerja terhadap suatu produktivitas kerja karyawan, sehingga karyawan yang mengalami stres kerja harus tetap memiliki produktivitas kerja yang baik. Adapun pernyataan dari Ekundayo (2014) yaitu organisasi harus menganggap stres kerja sebagai masalah manajemen dan bukan masalah individu, sehingga organisasi harus menangani stres kerja secara positif untuk meningkatkan produktivitas kerja karyawan. 
Dari ketiga alasan tersebut, didukung dengan temuan dari Dar, Akmal, Naseem, dan Khan (2011) dan Ojo, Ogunleye, dan Olatunji (2014) yang mengungkapkan bahwa stres kerja memiliki efek positif pada karyawan dari organisasi manapun. Oleh karena itu, karyawan mampu untuk bertoleransi dengan stres kerja dan mampu memiliki pandangan yang lebih baik, sehingga dapat memicu hasil kerja yang positif.

\section{SIMPULAN}

Berdasarkan penelitian yang telah dilakukan oleh penulis diperoleh hasil bahwa terdapat hubungan yang positif dan signifikan antara stres kerja dengan produktivitas kerja karyawan di PT Politama Pakindo Ungaran.

\section{Saran}

Adapun saran penulis berdasarkan dari hasil penelitian antara lain sebagai berikut:

1. Bagi Perusahaan

Bagi pihak manajemen perusahaan hendaknya memberikan sebuah kesempatan yang sama kepada setiap karyawan agar dapat berlatih untuk menghadapi sebuah tekanan yang moderat, sehingga dapat memampukan karyawan agar bisa bertahan dan mengelolanya dengan baik untuk meningkatkan produktivitas kerja mereka. Adapun beberapa cara yang dapat dilakukan antara lain memberikan kesempatan untuk berkompetisi meningkatkan daya tahan agar dapat bekerja lebih produktif, misalnya melalui diskusi, focus group discussion (FGD), dan memberikan sebuah pelatihan seperti pelatihan problem solving kepada karyawan.

\section{Bagi Karyawan}

Setiap karyawan diharapkan dapat memanfaatkan sebuah peluang untuk memahami situasi dimana sebuah situasi tersebut menjadikan diri mereka stres, sehingga setiap karyawan memiliki daya tahan lebih kuat dalam menghadapi sebuah tekanan. Dengan demikian karyawan dapat merasakan bahwa tekanan tersebut diubah menjadi tantangan yg harus dihadapi untuk dapat meningkatkan produktivitas kerja mereka. Ada beberapa cara yang dapat digunakan oleh karyawan misalnya berkompetisi dalam meningkatkan produktivitas kerja.

\section{Bagi Peneliti Selanjutnya}

Bagi peneliti selanjutnya, diharapkan mampu menambahkan faktor-faktor lainnya yang mempengaruhi produktivitas kerja karyawan selain stres kerja seperti faktor pendidikan \& pelatihan, motivasi, keterampilan kerja, kedisiplinan, dan juga etos kerja. 


\section{DAFTAR PUSTAKA}

Andriani, A. A. (2017). Hubungan stress kerja terhadap produktivitas kerja pegawai di kantor dinas kebersihan dan pertamanan kota Samarinda. eJournal Administrasi Negara, 5(1), 5555-5565. https://docplayer.info/54159731-Hubungan-stress-kerja-terhadapproduktivitas-kerja-pegawai-di-kantor-dinas-kebersihan-dan-pertamanan-kotasamarinda.html

Asbari, M., Santoso, P. B., \& Purwanto, A. (2019). Pengaruh kepemimpinan dan budaya organisasi terhadap perilaku kerja inovatif pada industri 4.0. JIMUPB Jurnal Ilmiah Manajemen, 8(1), 7-15. https://doi.org/10.33884/jimupb.v8i1.1562

Azwar, S. (2012). Reliabilitas dan validitas. Yogyakarta: Pustaka Pelajar.

Azwar, S. (2018). Metode penelitian psikologi edisi ke-2. Yogyakarta: Pustaka Pelajar.

Bamidele, O., Adedeji, O., \& Samuel, O. (2014). Impact of job stress on the job performance of nigeria security and civil defence corps members. Research on Humanities and Social Sciences, 4(26), 166-176. https://www.iiste.org/Journals/index.php/RHSS/article/view/17659/17784

Charity., \& Etebu. (2016). Impact of stress on employee's productivitu in financial institution in Nigeria. European Journal of Business and Management, 8(19), 105-109. https://www.iiste.org/Journals/index.php/EJBM/article/view/31646

Cherny, B. K., \& Kartikasari, D. (2017). Pengaruh stres dan motivasi terhadap produktivitas kerja karyawan pada PT Epson Batam. Jurnal Akuntansi, Ekonomi dan Manajemen Bisnis, 5(1), 80-90. https://core.ac.uk/download/pdf/229851485.pdf

Dar, L., Akmal, A., Naseem, M. A., \& Khan, K. U. D. (2011). Impact of stress on employees job performance in business sector of Pakistan. Global Journal of Management and Business Research, 11(6), 0-4. https://globaljournals.org/GJMBR_Volume11/1Impact-of-Stress-on-Employees-Job-Performance.pdf

Damri, Z. N. U. (2017). Pengaruh komitmen organisasi, kepuasan kerja, dan kepemimpinan terhadap disiplin kerja pegawai biro administrasi pemerintahan umum provinsi Riau. JOM Fekon, 4(1), 656-667. https://www.neliti.com/publications/120241/pengaruhkomitmen-organisasi-kepuasan-kerja-dan-kepemimpinan-terhadap-disiplin-k

Ekundayo, J. A. (2014). Occupational stress and employees productivity in the workplace. International Journal of Scientific Research in Education, 7(2), 157-165. http://www.ijsre.com/assets/vol.\%2C-7_2_-ekundayo.pdf

Tahir, A. (2014). Perilaku organisasi (1 $1^{\text {th }}$ ed.). Yogyakarta: Deepublish. 
Dwamena, M. A. (2012). Stress and its effects on employees productivity-a case study of ghana ports and habours authority, Takoradi. KNUSTSpace. http://ir.knust.edu.gh/bitstream/123456789/4835/1/Mark\%20A.\%20Dwamena.pdf

Safitri, A. E., \& Gilang, A. (2019). Pengaruh stres kerja terhadap produktivitas kerja karyawan pada PT. Telkom Witel Bekasi. Jurnal Ecodemica, 3 (2), 170-180. https://doi.org/10.31311/jeco.v3i2.5918

Golden, L. (2012). The effects of working time on productivity and firm performance, research synthesis paper. ResearchGate. https://www.researchgate.net/publication/256035039_The_Effects_of_Working_Time _on_Productivity_and_Firm_Performance_Research_Synthesis_Paper

Harrisma, O. W., \& Witjaksono, A. D. (2013). Pengaruh stres kerja terhadap produktivitas kerja melalui kepuasan kerja. Jurnal Ilmu Manajemen, 1(2), 650-652. https://core.ac.uk/download/pdf/230760198.pdf

Lucia, R. H., Kawet, L., \& Trang, I. (2015). Pengaruh konflik dan stres kerja terhadap produktivitas kerja dimediasi oleh kepuasan kerja karyawan universitas katolik De La Salle Manado. Jurnal Emba, 3(3), 719-728. https://media.neliti.com/media/publications/2735-ID-pengaruh-konflik-dan-streskerja-terhadap-produktivitas-kerja-dimediasi-oleh-kep.pdf

Mahoney, T, A., Jerdee, T. H., \& Caroll, S. J. (1963). Development of Managerial Performance: A Research Approach, Cincinnati: South Western Publ Co.

Mathis, R. L., \& Jackson, J. H. (2008). Human resource management twelfth edition. SouthWestern: Thomson.

Michac, J. (1997). Stress and productivity. Trexima: Slovak Republic.

Ojo, B. B., Ogunleye, A. J., \& Olatunji, S. O. (2014). Impact of job stress on the job performance of Nigeria security and civil defence corp members. Humanities and social sciences, $4(26)$, 166-175. https://www.iiste.org/Journals/index.php/RHSS/article/view/17659/17784

Putri, A. K. (2015). Pengaruh stress dan disiplin terhadap produktivitas kerja karyawan supporting pada PT. Indah Kiat Pulp and Paper TBK di Perawang. Jom Fekon, 2(1), 118. https:/www.neliti.com/publications/33794/pengaruh-stress-dan-disiplin-terhadapproduktivitas-kerja-karyawan-supporting-pa

Rawal, A., \& Mhatre, S. (2018). A study on work stress and its impacts on employee's productivity with respect to teacher's (self financing). IOSR Journal of Business and 
Management

(IOSR-JBM),

$2278-487(2319-7668)$,

$15-23$.

http://www.iosrjournals.org/iosr-jbm/papers/Conf.ADMIFMS1808-2018/Volume1/3.\%2015-23.pdf

Robbins, S. P. (2003). Perilaku organisasi jilid ke-2. Jakarta: Gramedia Pustaka Utama.

Robbins, S. P. (1996). Perilaku organisasi jilid ke-2. Jakarta: PT Prenhallindo.

Saefullah, E., Listiawati., \& Amalia, A. N. (2017). Pengaruh beban kerja dan stres kerja terhadap produktivitas kerja karyawan. Jurnal Akademika, 15(2),117-122.

Siagian, S. P. (2007). Manajemen sumber daya manusia. Jakarta: Bumi Aksara.

Sugiyono. (2011). Metode penelitian kuantitatif, kualitatif dan R\&D. Bandung: Alfabeta.

Sorongan, J., South, L. F., \& Boky, H. (2018). Hubungan antara stres kerja dan upah dengan produktivitas kerja pada pegawai di dinas kesehatan kota Manado. Jurnal Kesmas, 7(5), 1-8. https://ejournal.unsrat.ac.id/index.php/kesmas/article/view/22023

Spector, P. E. (2006). Industrial and organizational psychology research \& practice (4nd Ed). USA: John Willey \& Sons.Inc.

Stranks, J. (2005). Stress at work. Heinemann: Elsevier Butterworth.

Sunyoto, A. (2007). Manajemen sumber daya manusia untuk perusahaan. Jakarta: Rajagrafindo Persada.

Tarwaka., Bakri, S. H. A., \& Sudiajeng, L. (2004). Ergonomi untuk keselamatan, kesehatan kerja dan produktivitas.Surakarta: UNIBA PRESS.

Timpe, D. (2002). Seri sumber daya manusia produktivitas. Cetakan kelima. Jakarta: PT. Gramedia.

Wingjosoebroto, S. (1992). Pengantar teknik \& manajemen industri. Surabaya: Guna Widya.

Zulkarnaen, W., Suarsa, A., \& Kusmana, R. (2018). Pengaruh pelatihan kerja dan stres kerja terhadap produktivitas kerja karyawan bagian produksi departemen r-pet pt. namasindo plas Bandung barat. Jurnal Ilmiah MEA, 2(3), 151-177. https://doi.org/10.31955/mea.vol2.iss3.pp151-177 